\title{
Comparative study of two autogenous graft techniques using piezosurgery for sinus lifting $^{1}$
}

\author{
Estudo comparativo de duas técnicas de enxerto autógeno utilizando piezocirurgia para \\ levantamento de seio maxilar
}

\author{
Geraldo Prestes de Camargo Filho', Luciana CorrêaII, Claudio Costa ${ }^{\mathrm{III}}$, Claudio Mendes Pannuti ${ }^{\mathrm{IV}}$, Rainer Schmelzeisen ${ }^{\mathrm{V}}$, João \\ Gualberto de Cerqueira Luz ${ }^{\mathrm{VI}}$
}

\author{
${ }^{I}$ Master, Dentistry School, Department of Surgery, USP, Sao Paulo-SP, Brazil.

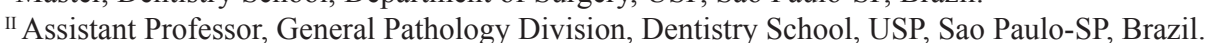 \\ III Associate Professor, Radiology Division, Dentistry School, USP, Sao Paulo-SP, Brazil. \\ ${ }^{\text {IV }}$ Assistant Professor, Periodontology Division, Dentistry School, USP, Sao Paulo-SP, Brazil. \\ ${ }^{v}$ Associate Professor, Division of Oral and Maxillofacial Surgery, University Medical Centre Freiburg, Germany. \\ ${ }^{v 1}$ Associate Professor, Traumatology Division, Dentistry School, USP, Sao Paulo-SP, Brazil.
}

\begin{abstract}
Purpose: Maxillary sinus lifting is a technique, in which, a possible complication is sinus membrane perforation. The aim of this study was to compare two techniques using ultrasound surgery to perform autogenous graft for maxillary sinus lifting. Methods: Ten rabbits were used in the study, one of them did not undergo surgery. The other nine rabbits had their maxillary sinuses filled with autogenous bone grafts collected from the external skull diploe in particulate form on the right side, and shaved on the left side, both with ultrasonic device. Data on bone density in left and right maxillary sinus, obtained by computed tomography in transverse and longitudinal sections, recorded 90 days after the grafts, were statistically compared. Results: There were no statistically significant differences between the two techniques that used shaved and particulate bone collected by means of ultrasonic device from rabbit skulls. Conclusion: Assessment of operative procedures led to the conclusion that piezoelectric ultrasound was shown to be a safe tool in the surgical approach to the maxillary sinus of rabbits, allowing sinus membrane integrity to be maintained during surgical procedures. Key words: Maxillary Sinus. Autologous. Ultrasonics. Rabbits.
\end{abstract}

\section{RESUMO}

Objetivo: A técnica de levantamento de seio maxilar apresenta como possível complicação a perfuração da membrana sinusal. O presente trabalho teve por objetivo comparar duas técnicas que utilizam a cirurgia ultrassônica para realização de enxerto autógeno para levantamento de seio maxilar. Métodos: Dez coelhos foram utilizados no estudo, sendo que um deles não foi submetido a procedimento cirúrgico. Os nove coelhos operados tiveram os seios maxilares preenchidos com enxertos autógenos coletados de díploe externa de calota craniana, nas formas particulado do lado direito e raspado do lado esquerdo, ambos com aparelho ultrassônico. Os dados de densidade óssea nos seios maxilares esquerdo e direito, obtidos por meio de tomografia computadorizada nos sentidos transversal e longitudinal, registrados 90 dias após a realização dos enxertos foram comparados estatisticamente. Resultados: não houve diferenças estatisticamente significantes entre as técnicas de enxerto que utilizaram osso raspado e particulado coletado por meio de dispositivo ultrassônico da calota craniana de coelhos. Conclusão: A avaliação clínica dos procedimentos nos levou a concluir que o ultrassom piezoelétrico mostrou-se um instrumento clinicamente seguro na abordagem cirúrgica do seio maxilar de coelhos, permitindo a manutenção da integridade da membrana sinusal durante as manobras de ostectomia da parede lateral da maxila e divulsão da membrana sinusal.

Descritores: Seio Maxilar. Transplante Autólogo. Ultrassom. Coelhos.

${ }^{1}$ Research performed at Dentistry School, Department of Surgery, University of Sao Paulo (USP), Brazil.

\section{Introduction}

Rehabilitation with the use of dental implants requires the presence of sufficient bone tissue to stabilize the implants and consequent occurrence of the phenomenon of osseointegration. Frequently, however, the patient does not have a sufficient quantity of bone tissue height or thickness. or both, required for the placement of dental implants ${ }^{1}$. In these cases, it is necessary to resort to grafting techniques that make it feasible to place implants in the edentulous area. Thus, the autogenous type of graft has been shown to be the most indicated ${ }^{2,3}$, in spite its negative point being the morbidity of a donor area unrelated to the area to be reconstructed. A widely used technique for augmenting bone tissue volume in the maxilla is maxillary sinus lifting, in which, by 
means of osteotomy of the anterior maxillary sinus wall, the sinus membrane is exposed, and must be divulsed to obtain a receptor site for the bone tissue. One of the most common accidents in this technique is perforation of the sinus membrane while performing osteotomy which, in some cases may make a further surgical procedure unfeasible ${ }^{4}$.

Vercellotti et al. ${ }^{5}$ was a pioneer when he presented the use of piezoelectric ultrasound as a new alternative in performing osteotomies in maxillary sinus lifting surgeries. In 2004, once again Vercellotti ${ }^{6}$ published an article in which he provided technical characteristics about the equipment previously used, in addition to showing applications of piezoelectric surgery in maxillary sinus lifting and periodontal surgeries. The piezoelectric effect is given by the deformation of crystals and ceramics when stimulated by an electric current, which results in ultrasonic frequency oscillations. The osteotomy is performed by means of pendular vibratory movements, with nanometric variations of amplitude, by the use of various points. As an example of an ultrasonic device available on the Brazilian market, the Piezomaster (DK Driller) appliance is mentioned, which has different point designs that allow sinus osteotomy, removal of a block graft associated with chisels, as well as the removal of shaved graft to be performed.

Following the work of Vercellotti ${ }^{5,6}$, piezosurgery began to be used in different areas of Dentistry and articles began to appear in the scientific community relating the findings of the use of this new and promising tool. Thus, a complete literature review of the subject allows one to find the report of its use in alveolar nerve lateralization surgeries ${ }^{7}$, surgically assisted rapid maxillary expansions $^{8}$, orthognatic ${ }^{9,10}$ and maxillary sinus lifting surgeries ${ }^{11-15}$.

A type of radiographic analysis frequently used in the diagnosis and follow-up of patients who are candidates for, or have been submitted to grafting techniques is computerized tomography, which allows bone areas to be evaluated by means of measurements and different densities with great precision ${ }^{16}$. Cone Beam Computerized Tomography (CBCT) favors the obtainment of images with lower radiation doses and reduced cost, due to its technology capable of producing images with submillimetric isotropic spatial resolution. It is indicated especially for the dentomaxillofacial region ${ }^{17}$.

Careful study based on the use of the ultrasonic technique both in the approach to the anterior maxillary sinus wall and in the removal of bone tissue from the donor area will allow the opening of a new front in the arsenal of equipment and new techniques in Implant Dentistry, and Oral and Maxillofacial Surgery as well as in other areas of health. For these reasons, the aim of the present study was to compare, by means of computerized tomography, two techniques of autogenous grafts collected from the external diploe of the skull cap of rabbits, in the particulate and shaved forms, both with the use of an ultrasonic appliance.

\section{Methods}

Ten adult male rabbits were used in this study, one of them (1 rabbit) was not submitted to any surgical procedure, acting as control, and 9 rabbits were submitted to bilateral maxillary sinus lifting surgeries, with the donor area being the external diploe of the skull cap.
For surgical access to the maxillary sinuses, the animals were placed lying on their sides; a cutaneous incision of approximately $2 \mathrm{~cm}$, and divulsion in planes was made to expose the bone tissue. After this an osseous window $3 \mathrm{~mm}$ in diameter was made, with complete removal of the vestibular bone plate and exposure of the sinus membrane, by means of a spherical ultrasonic diamond point, activated by the Piezosonic appliance (VK Driller, Sao Paulo-SP, Brazil) at a maximum power of 50 watts, maximum frequency of $100 \mathrm{MO}$ and continuous irrigation with $0.9 \%$ saline solution. The sinus mucosa was initially divulsed by an ultrasonic tip (ES004 VK Driller, Sao Paulo-SP, Brazil) and carefully moved with the Freer detacher (Quinelato, Brazil) until it was completely divulsed.

For removing the bone from the external diploe of the skull cap, a median incision of approximately $4 \mathrm{~cm}$ was made and dissection in planes to expose the bone tissue. An imaginary median line divided the rabbits' skull caps into two donor areas: right and left. From the right side area, bone blocks measuring approximately $1 \mathrm{x} 1 \mathrm{~mm}$ with the depth of the external diploe, were removed by means of an ultrasonic tip of the periotome type, activated by the same ultrasonic appliance. Removal of these blocks was finalized with a straight $3 \mathrm{~mm}$ double bevel chisel with an active tip (Quinelato, Brazil). The bone particles were immediately placed in the receptor bed of the right maxillary sinus. From the left donor area, shaved bone was removed with a hoe-shaped ultrasonic tip, with the appliance set up using the same parameters. The antero-posterior movements, the tip shape and the characteristics of the piezosonic technique allowed the collection of shaved bone, which was immediately placed in the receptor bed of the left maxillary sinus. The quantities of bone removed from the donor areas were sufficient to completely fill both the left and right maxillary sinuses.

The graft receptor area was sutured in layers, so that in the internal portion, Vicryl 3-0 (Ethicon, Johnson \& Johnson) was used with simple stitches, and Nylon 3-0 (Ethicon, Johnson $\&$ Johnson) was used in the skin. The graft donor area was sutured in a single layer with Nylon 3-0 (Ethicon, Johnson \& Johnson).

After 90 days, the animals were sacrificed and their heads placed in glass containers with a $10 \%$ formol solution for fixation. One month later, bone density was evaluated by means of cone beam computerized tomography (NewTom 3G -NIM s.r.l., Verona, Veneto, Italy). In the axial plane selected for the readout of each rabbit, one of the tools of the software itself was applied, which allowed the bone density to be measured: tomodensitometric gray scale. After acquisition of the tomographic images, a sample was removed of the tissue in the operated region, Using a trephine bur $4 \mathrm{~mm}$ in diameter on the right and lefts sides of the 10 rabbit heads, to obtain histological slides in which Hematoxylin-Eosin (HE) and Masson's Trichrome stains were used.

Images of the histologic field were digitized and morphometrically analyzed with regard to cellularity, collagen fibers and neoformed bone. The data on bone density in the left and right maxillary sinuses, in the transversal and longitudinal directions were statistically compared, using the $t$ test for paired samples in the case of the longitudinal variable, and the Wilcoxon non parametric test for the transversal variable, adopting a level of significance of $5 \%$. 


\section{Results}

During the course of the ultrasonic surgical technique to approach the rabbits' maxillary sinuses, no rupture of the sinus on both the right and left sides was observed in the operated animals.

To characterize the studied sample, the mean and median density values to summarize the information, and standard deviations to indicate the variability of the data are presented in Table 1. Higher mean values were noted for the group that received the shaved bone for both directions evaluated.

TABLE 1 - Mean, median, standard deviation values of bone density of the maxillary sinuses of rabbits and comparison of the experimental groups (gray tone scale values of the software QR NNT version 2.02)

\begin{tabular}{llccc}
\hline & & Particulated & Shaved & $\mathrm{p}$ \\
\hline Longitudinal & & & & \\
& $\mathrm{N}$ & 09 & 09 & 0.898 \\
& Mean & 6766.63 & 6801.11 & (paired t test) \\
& Median & 6715.75 & 6867.00 & \\
& $\mathrm{SD}^{\dagger}$ & 805.13 & 657.54 & \\
\hline Transversal & & & & \\
& $\mathrm{N}$ & 09 & 09 & 0.594 \\
& Mean & 6702.63 & 6747.97 & \\
& Median & 6516.50 & 6923.75 & (Wilcoxon) \\
& $\mathrm{SD}^{\dagger}$ & 1036.75 & 679.66 & \\
\hline
\end{tabular}

$\uparrow \mathrm{SD}=$ standard deviation

When analyzing the above results, no significant difference was verified between the particulated and shaved groups, with as regards the longitudinal $(\mathrm{p}=0.898)$ and the transversal $(\mathrm{p}=0.594)$ planes.

The histopathologic analysis of the shaved bone group revealed a fragment of the maxillary sinus exhibiting mucosa from the whole anterior plate and posterior bone plate. Locally, in the respiratory epithelium of the mucosa, hyperplastic areas and isolated lymphoid aggregates were observed. Anteriorly to the posterior bone plate, non coalescent trabeculae composed of mature tissue were noted in the midst of loose conjunctive tissue and richly vascularized adipose tissue (Figure 1A). Osteoblasts organized in a single layer at the periphery of the trabeculae and osteocytes in a homogeneous distribution pattern were evident (Figure 1B). Occasional osteoclasts were seen at the periphery of the trabeculae, exhibiting Howship lacunae. Intense hyperemia was present (Figure 1A). Serous glandular tissue exhibited aspects of normality.

Histopathologic analysis of the particulated bone group revealed aspects similar to those of the previous situation (Figure 1C). Inside the sinus, however, a lower number of more extensive and coalescent trabeculae, composed of more immature bone tissue were observed, in comparison with the previous situation. In some specimens it was possible to visualize fibrous conjunctive tissue around these trabeculae, exhibiting large quantities of osteoprogenitor cells and others with a morphology indicative of osteoblast differentiation (Figure 1D). Intense vascularization and hyperemia were also present (Figure 1C).

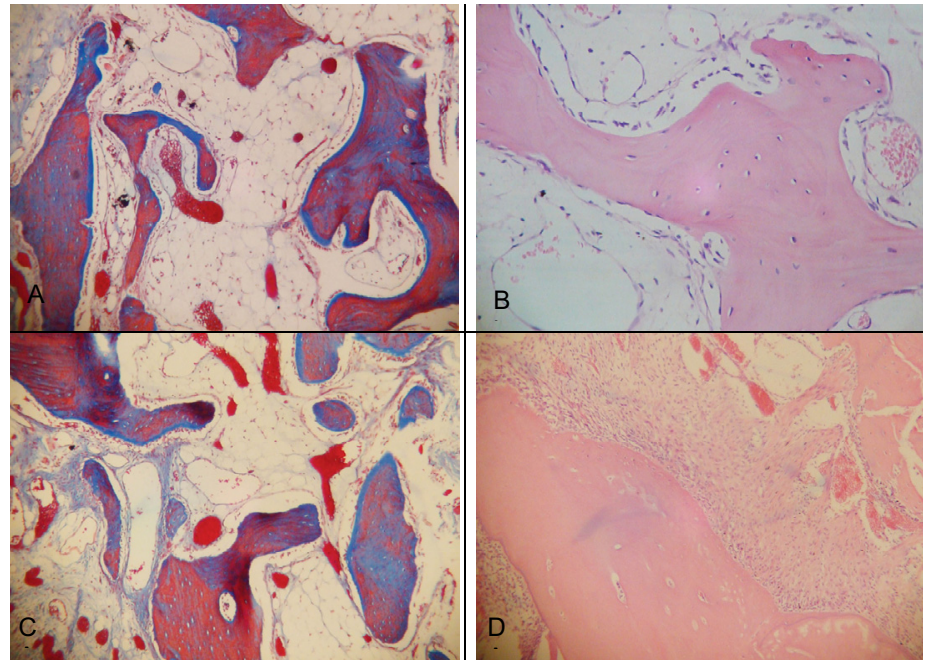

FIGURE 1 - A and B: Shaved bone group; $\mathbf{C}$ and D: particulated bone group. A: Interior of the maxillary sinus exhibiting non-coalescent mature trabeculae. The stroma is composed of richly vascularized adipose tissue exhibiting intense hyperemia (Masson's Trichrome, at 100X final magnification). B: Detail of a bone trabecula in which homogeneously distributed osteocytes, a peripheral osteoblast line and lines of bone apposition giving an aspect of mature bone are observed (HE, at 400X final magnification). C: Pattern similar to that of the group with shaved bone, with bone trabeculae disposed in a richly vascularized adipose stroma (Masson's Trichrome, at 100X final magnification). D: Detail of one of the specimens in which a single, more voluminous trabecula is noted in the sinus space, with fibrous tissue around it containing osteoprogenitor cells. This tissue suggests intense bone apposition (HE, at 400X final magnification)

\section{Discussion}

Piezosurgery appears to be an extremely advanced and conservative tool when compared with the existent methods for the treatment of bone and soft tissues. Authors whose studies have demonstrated the safety this technique offers with regard to the proximity of soft tissues such as nerves, vessels, mucosas, etc are in agreement with this opinion ${ }^{5,7-10,14,15}$.

An important feature of the piezoelectric device, according to unanimous agreement among the authors who have used it, is the selective cutting of only mineralized structures, without damaging soft tissues. This characteristic is due to the low frequency of the ultrasonic waves and the shape of the tip used. It is especially important when performing delicate surgeries that involve proximity to nerve tissues, such as, for example in the inferior alveolar nerve lateralization technique ${ }^{7}$ or even in the removal of autogenous grafts from the skull cap ${ }^{18,19}$. The selectivity of the cut is also extremely interesting in lateral approaches to the maxillary sinus, where the integrity of the sinus membrane is a preponderant factor in the success of sinus floor lifting techniques.

It is relevant to discuss the influence of piezoelectric osteotomy in relation to bone morphology and cellular viability. One study, made a comparison by means of morphometric analysis of slices of autogenous bone harvested by ultrasound or conventional cutters and found no statistically significant differences between 
the two groups. They observed that the slices of autogenous bone harvested with ultrasound contained vital cells which differentiated into osteoblasts, a finding that coincides with the illustrative analysis of this study, in which osteoprogenitor cells and other cells with morphology indicative of osteoblast differentiation were observed ${ }^{20}$.

The disadvantage of piezoelectric surgery, according to some authors studied, lies in the longer operative time demanded $^{11,12,14}$. An important factor to be discussed as regards this theme is the power of the equipment and the characteristics of the bone to be cut. It is evident that more compact bones, such as the external diploe of the skull cap in which the work in this study was done, requires the use of more powerful equipment and suitable parameters. Moreover, it is believed that every new technology demands that the operator must be trained, in order to obtain the maximum benefit of the technological resources available. In the authors' opinion, piezoelectric ultrasound is a most valuable tool in dental surgeries, consisting of an extremely safe and certainly efficient method in the hands of a trained and experienced professional.

The external diploe of the skull cap was selected as the donor area in the present study, because of the very easy surgical access, good quantity of bone tissue to be removed, ease of extending access should it be necessary to remove a larger quantity of bone, little functional and esthetic morbidity, in addition to presenting predictable results when used in reconstructions. Moreover, it has been pointed out that bones of the membranous-mandible and skull cap type present less resorption in comparison with those of the endochondral-iliac, tibia and rib type ${ }^{3}$.

During the surgical procedure, a factor to be emphasized was the comfort of using piezoelectric ultrasound for removing the graft from the external diploe of the skull cap knowing that there was a minimal risk of lesion to the dura-mater in case of any accident occurring, as has previously been demonstrated ${ }^{18,19}$.

With regard to the surgical technique of maxillary sinus lifting, studies have shown a high rate of rupture of the sinus membrane during the maneuvers of divulsion, which could compromise the result of treatment. The main causes found for rupture of the sinus membrane are operative accidents, generally related to the learning curve and extreme fragility of the sinus membrane in some patients ${ }^{4}$.

The importance of $\mathrm{CT}$ in the evaluation of bone density thanks to its sensitivity has been demonstrated, allowing the quantification of exclusively medullary bone and monitoring of alterations in mineralization ${ }^{16}$. The use of CT is also confirmed in the evaluation of the quality, adaptation and transformation of vascularized bone grafts, proving its clinical application ${ }^{16}$.

The results of the tomographic evaluation in the present research revealed no statistically significant differences between the bone density means of the right (particulated bone) and left (shaved bone) sides, both in the transversal and longitudinal direction of the maxillae. One believes that the biological effects of piezosurgery allowed the shaved bone, in spite of the way in which it was collected favoring a possibly larger area of necrosis, to reach a result similar to that of the particulated bone. In some ways, the results were not surprising, as one believed that the shaved bone, because of allowing the collection of a larger volume and more complete filling of the maxillary sinus, would result in higher density levels than those of particulated bone, which did not occur. In the authors' view, this once again demonstrates the importance of the biological effects of piezosurgery, with less thermal damage and maintenance of greater cellular viability. Comparison of the results obtained in the present study with those of other studies evaluated was prejudiced, since different methodologies were used.

Although the histological analysis was merely illustrative, it revealed similar patterns for the two groups - shaved bone and particulated bone - which is an indication of the feasibility of using both techniques in maxillary sinus lifting surgeries. The findings of the present study are corroborated by another study that demonstrated a percentage of $55 \%$ of vital bone, characterized by the presence of osteocytes in bone collected by piezosurgery ${ }^{18}$.

\section{Conclusion}

Piezoelectric ultrasound was shown to be a safe tool in the surgical approach to the maxillary sinus of rabbits, allowing sinus membrane integrity to be maintained during surgical procedures.

\section{References}

1. Davarpanah M, Martinez H, Tecucianu JF, Hage G, Lazzara R. The modified osteotome technique. Int J Periodontics Restorative Dent. 2001;21(6):599-607.

2. Woo I, Le BT. Maxillary sinus floor elevation: review of anatomy and two techniques. Implant Dent. 2004;13(1):28-32.

3. Schlegel KA, Schultze-Mosgau S, Wiltfang J, Neukam FW, Rupprecht $\mathrm{S}$, Thorwarth $\mathrm{M}$. Changes of mineralization of free autogenous bone grafts used for sinus floor elevation. Clin Oral Implants Res. 2006;17(6):673-8. 4. Constantino A. Elevação de seios maxilares com perfuração de membrana - estudo prospectivo clínico e histológico de 4 anos. Rev Bras Implant. 2002;8(3):8-11.

5. Vercellotti T, De Paoli S, Nevins M. The piezoelectric bony window osteotomy and sinus membrane elevation: introduction of a new technique for simplification of the sinus augmentation procedure. Int $\mathrm{J}$ Periodontics Restorative Dent. 2001;21(6):561-7.

6. Vercellotti T. Technological characteristics and clinical indications of piezoelectric bone surgery. Minerva Stomatol. 2004;53(5):207-14.

7. Camargo Filho GP, Vilela A, Deboni MCZ. A utilização de pontas ultrassônicas nos procedimentos de lateralização do nervo alveolar inferior. Rev Cat Implant. 2008;8(10):28-30.

8. Camargo Filho GP, Fudimori F, Kfouri FA, Pastore GP, Andrade ALMV. Motores de corte ultra-sônico, uma nova tecnologia para auxiliar as expansões rápidas da maxila assistidas cirurgicamente. Rev Bras Implant. 2009;15(2):16-8.

9. Gruber RM, Kramer H, Merten A, Schliephake H. Ultrasonic surgery - an alternative way in orthognathic surgery of mandible. A pilot study. Int J Oral Maxillofac Surg. 2005;34(6):590-3. 
10. Landes CA, Stübinger S, Williger B, Sader R. Critical evaluation of piezoeletric osteotomy in orthognatic surgery: operative technique, blood loss, time requirement, nerve and vessel integrity. J Oral Maxillofac Surg. 2008;66(4):657-74.

11. Eggers G, Klein J, Blank J, Hassfeld S. Piezosurgery: an ultrasound device for cutting bone and its use and limitations in maxillofacial surgery. Br J Oral Maxillofac Surg. 2004;42(5):451-3.

12. Stübinger S, Kuttenberger J, Fillipi A, Sader R, Zeilhofer HF. Intraoral piezosurgery: preliminary results of a new technique. J Oral Maxillofac Surg. 2005;63(9):1283-7.

13. Vercellotti T, Pollack AS. A new bone surgery device: sinus grafting and periodontal surgery. Compend Contin Educ Dent. 2006;27(5):319-25. 14. Kfouri FA, Duailibi MT, Bretos JLG, Ferreira LM, Duailibi SE. Cirurgia piezoelétrica em implantodontia: aplicações clínicas. RGO. 2009;57(1):121-6.

15. Camargo Filho GP, Andrade ALMV. Cirurgia ultrassônica: maior eficiência e segurança no levantamento do seio maxilar. Rev Bras Implant. 2009;15(1):11-3.
16. Buscatti MY. Contribuição para o estudo das densidades ósseas maxilomandibulares por meio da escala tomodensitométrica de Hounsfield quando da aplicação de programa computadorizado para planejamento de implantes osseointegrados [Dissertação]. São Paulo: Universidade de São Paulo, Faculdade de Odontologia; 2003.

17. Loubele M, Guerrero ME, Jacobs R, Suetens P, Steenberghe DV. A comparison of jaw dimensional and quality assessments of bone characteristics with cone-beam $\mathrm{CT}$, spiral tomography, and multi-slice spiral CT. Int J Oral Maxillofac Implants. 2007;22(3):446-54.

18. Berengo M, Bacci C, Sartori M, Perini A, Della Barbera M, Valente M. Histomorphometric evaluation of bone grafts harvested by different methods. Minerva Stomatol. 2006;55(4):189-98.

19. Kotrikova B, Wirtz R, Krempien R, Blank J, Eggers G, Samiotis A, Mühling J. Piezosurgery - a new safe technique in cranial osteoplasty? Int J Oral Maxillofac Surg. 2006;35(5):461-5.

20. Chiriac G, Herten M, Schwartz F, Rothamel D, Becker J. Autogenous bone chips: influence of a new piezoelectric device (Piezosurgery) on chip morphology, cell viability and differentiation. Clin Periodontol. 2005;32(9):994-9.

Conflict of interest: none

Financial source: none

\section{Correspondence:}

Prof. Dr. João Gualberto de Cerqueira Luz

Rua Duarte de Azevedo, 284/22

02036-021 São Paulo - SP Brasil

Fax: (55 11)2959-6266

jgcluz@usp.br

Received: March 09, 2010

Review: May 11, 2010

Accepted: June 21, 2010

\section{How to cite this article}

Camargo Filho GP, Corrêa L, Costa C, Pannuti CM, Schmelzeisen R, Luz JGC. Comparative study of two autogenous graft techniques using piezosurgery for sinus lifting. Acta Cir Bras. [serial on the Internet] 2010 Nov-Dec;25(6). Available from URL: http://www.scielo.br/acb

*Color figure available from www.scielo.br/acb 